Article

\title{
Self-Assembly of Short Elastin-like Amphiphilic Peptides: Effects of Temperature, Molecular Hydrophobicity and Charge Distribution
}

\author{
Meiwen Cao ${ }^{1} * \mathbb{D}$, Yang Shen ${ }^{1}$, Yu Wang ${ }^{1}$, Xiaoling Wang ${ }^{2}$ and Dongxiang $\mathrm{Li}^{3}$ \\ 1 State Key Laboratory of Heavy Oil Processing and Centre for Bioengineering and Biotechnology, China \\ University of Petroleum (East China), 66 Changjiang West Road, Qingdao Economic Development Zone, \\ Qingdao 266580, China; shenyang52633@163.com (Y.S.); m18254289278@163.com (Y.W.) \\ 2 Personnel Department and School of Blue Economy Engineering, Qingdao Vocational and Technical College, \\ Qingdao Economic and Technological Development Zone, Qingdao 266555, China; wangxl@qtc.edu.cn \\ 3 Shandong Key Laboratory of Biochemical Analysis, College of Chemistry and Molecular Engineering, \\ Qingdao University of Science and Technology, Qingdao 266042, China; lidx@qust.edu.cn \\ * Correspondence: mwcao@upc.edu.cn; Tel./Fax: +86-532-86983455
}

Academic Editor: He Dong

Received: 21 December 2018; Accepted: 7 January 2019; Published: 8 January 2019

\begin{abstract}
A novel type of self-assembling peptides has been developed by introducing the basic elastomeric $\beta$-turn units of elastin protein into the amphiphilic peptide molecules. The self-assembly behaviors of such peptides are affected by the overall molecular hydrophobicity, charge distribution and temperature. The molecules with higher hydrophobicity exhibit better self-assembling capability to form long fibrillar nanostructures. For some peptides, the temperature increase can not only promote the self-assembly process but also change the self-assembly routes. The self-assembly of the peptides with two charges centralized on one terminal show higher dependence on temperature than the peptides with two charges distributed separately on the two terminals. The study probes into the self-assembly behaviors of short elastin-like peptides and is of great help for developing novel self-assembling peptides with thermo sensitivity.
\end{abstract}

Keywords: amphiphilic peptides; elastin-like peptides; elastomeric $\beta$-turn units; temperaturesensitivity; self-assembly

\section{Introduction}

Elastin is an insoluble extracellular-matrix protein that imparts elasticity to organs and tissues [1-3]. Tropoelastin is the soluble precursor of elastin. It can form elastic fibers, which then cross-link to produce elastin [4]. Tropoelastin contains two alternating domains, one hydrophilic domain rich in alanine $(\mathrm{A})$ and lysine $(\mathrm{K})$ residues and one hydrophobic domain rich glycine $(\mathrm{G}), \mathrm{A}$, valine $(\mathrm{V})$, and proline $(\mathrm{P})$ residues [5]. The hydrophilic domain provides cross-linking sites that can form covalent bonds to connect the polypeptide chains. The hydrophobic domain usually has repeated $\beta$-turn peptide sequences such as VPGG, VPGVG and APGVGV [1,6-11], which can introduce specific viscoelasticity and temperature-sensitivity to the molecule [8,9].

Inspired by elastin, elastin-like polypeptides (ELPs) that are composed of the characteristic elastomeric units of tropoelastin have been developed as the artificial biopolymers [2,12]. ELPs usually show temperature-sensitive folding behaviors and they can give conformational changes upon heating $[13,14]$. It has been demonstrated that the VPGVG-based ELPs collapse from an extended chain to a type II $\beta$-turn conformation around the Pro-Gly pair with temperature increase [15-18]. Such a phenomenon is usually termed inverse temperature transition (ITT) $[13,19,20]$, which is suggested to be driven by dehydration of the hydrophobic valine side chains [21]. Very interestingly, short 
elastin-derived peptides with limited number (usually 1-5) of the repeating $\beta$-turn units have been shown to have similar temperature-sensitive conformational changes as ELPs [20-29]. Reiersen et al. showed that a single VPGVG unit can act as a thermodynamically independent unit to undergo the temperature-induced extended- $\beta$-turn transition [21]. The fact established that the temperature-driven conformational change is an intrinsic property of the individual $\beta$-turn sequence. Moreover, it has been found that the ITT temperature of an elastin-like peptide can be tailored through several aspects, such as adjusting the chain length, replacing residues in the repeating unit, varying groups and charges at the termini and so on [22,28,30,31]. These findings all serve as foundations for designing novel elastin-based short peptides that have temperature-responsive self-assembling properties [29,32-35].

Short amphiphilic peptides are one important category of self-assembling peptides that can form distinct nanostructures $[36,37]$. By having specific mechanistic property and high biocompatibility, these nanostructures show potential applications in vast areas including templates for nanostructure construction [38], scaffolds for tissue engineering [39,40], carriers for medicine delivery [41-43], and biological surface engineering [44,45]. It is of great interest to see whether we can develop temperature-responsive self-assembly molecules by involving the elastin $\beta$-turn units into the amphiphilic peptides. In the present study, a series of elastin-based peptides have been designed by introducing one or two VPGVG units into the amphiphilic peptide molecule, as shown in Table 1. The repeated I sequence (III) was designed to give hydrophobicity and self-assembling capability $[46,47]$. Two K residues were introduced to give positive charges. Their different positions in the molecules can provide evaluation of the effect of charge distribution on molecular self-assembly. For comparison, two molecules with only one VPGVG unit but without III segment were also synthesized. The study investigates the effects of molecular hydrophobicity, charge distribution and temperature on the self-assembly behaviors of the designed peptides. It bears great significance for the rational design of temperature-sensitive self-assembling peptides.

Table 1. Sequences of the designed short elastin-based peptides.

\begin{tabular}{cc}
\hline Peptide Sequence & Abbreviation \\
\hline Ac-KGVPGVGK-NH & \\
Ac-GVPGVGKK-NH & K-K8 \\
Ac-IIIKGVPGVGK-NH & KK8 \\
Ac-IIIGVPGVGKK-NH & IK-K11 \\
Ac-IIIKGVPGVGVPGVGK-NH & IKK11 \\
Ac-IIIGVPGVGVPGVGKK-NH & IK-K16 \\
\hline
\end{tabular}

\section{Experimental}

\subsection{Materials and Solution Preparation}

All of the peptide molecules were obtained from GL Biochem (Shanghai) Ltd. (Shanghai, China). The purity was $\geq 96 \%$. All solutions were prepared in water with a resistivity of $18 \mathrm{M} \Omega \mathrm{cm}$ that was obtained from a Millipore purification system (Millipore Corp, MA, USA). After adding water into the vial with peptide powder, the sample was treated with bath sonication for $15 \mathrm{~min}$. The solution $\mathrm{pH}$ was $4.5 \pm 0.3$ due to presence of adventitious trifluoroacetic acid in the sample. The fresh solutions were incubated at either $20^{\circ} \mathrm{C}$ or $80^{\circ} \mathrm{C}$ (sealed tightly and incubated in an air oven). All solutions were aged for at least one day for reaching equilibrium before equipment characterization.

\subsection{Fluorescence Measurement}

A Fluoro Max-P spectrophotometer (JOBIN YVON, Paris, France) was used for fluorescence measurements at room temperature. A $0.5 \mathrm{~cm}$ quartz cuvette was used. The critical aggregation concentrations (CACs) of each peptide were determined by using pyrene as a fluorescence probe. The emission spectra of pyrene in the 350-500 nm range were collected with excitation at $335 \mathrm{~nm}$. 
The pyrene polarity index $\mathrm{I}_{1} / \mathrm{I}_{3}$, that is, the ratio between the fluorescence intensities of peaks I and III, was calculated and plotted as a function of concentration.

\subsection{Atomic Force Microscopy (AFM)}

AFM measurements were carried out on a Multimode Nanoscope IVa AFM (Digital Instruments, Santa Barbara, CA, USA) under ambient conditions. TESP silicon probes with a nominal spring constant of $42 \mathrm{~N} / \mathrm{m}$ (Veeco, Santa Barbara, CA, USA) were used for collecting the tapping mode morphologies. The experimental parameters were as follows, scan speed: $1.0-1.8 \mathrm{~Hz}$, tip resonance frequency: $230-300 \mathrm{kHz}$, and drive amplitude: 20-100 mV. For sample preparation, a drop of 10-15 $\mu \mathrm{L}$ peptide solution was deposited onto a freshly cleaved mica surface. After adsorption for 5-30 s the sample was dried under a nitrogen stream. The sample was immediately subjected to AFM imaging. Analysis of the AFM results was carried out using the vendor-supplied software version V530r3sr3 (Veeco, Santa Barbara, CA, USA). In experiments, different nitrogen flow speeds were applied for sample preparation and no difference in the sample morphologies were found. This excluded the impacts of solvent evaporation and solvent gradient forces on the peptide self-assembled structures.

\subsection{Transmission Electron Microscopy (TEM)}

TEM measurements were performed on a JEM-2100UHR electron microscope (JEOL, Tokyo, Japan) at $200 \mathrm{kV}$. TEM samples were prepared using the negative staining method. Firstly, a carbon Formvar-coated copper grid was placed on a drop of peptide solution. After adsorption for about $8 \mathrm{~min}$, the grid was removed from the solution and then placed on a drop of uranyl acetate solution $(2 \% w / v)$ for negative staining. The samples were subjected to TEM characterization immediately after preparation.

\subsection{Circular Dichroism (CD)}

A MOS-450/AF-CD spectrophotometer (BioLogic, Paris, France) was used to collect the CD spectra. A $1.0 \mathrm{~mm}$ quartz cell was used. Scans were collected by taking points at $0.5 \mathrm{~nm}$ and an integration time of $0.5 \mathrm{~s}$. Three repeats were performed for each curve and the averaged results were given. Spectra smoothing and noise reduction were carried out using the vendor-supplied software.

\subsection{Fourier Transform Infrared Spectroscopy (FTIR)}

Infrared spectra were recorded on a Nicolet 6700 FT-IR spectrometer (Thermo Fisher Scientific, Waltham, MA, USA). The peptide solution was firstly deposited on a $\mathrm{CaF}_{2}$ plate and dried under vacuum. The peptide deposits were then resuspended with $\mathrm{D}_{2} \mathrm{O}$ and subsequently dried to form thin films. The resuspension procedure was repeated three times to ensure maximal hydrogen-to-deuterium exchange. The spectra were taken using a $4 \mathrm{~cm}^{-1}$ resolution and averaging of 128 scans.

\section{Results and Discussion}

\subsection{Determination of CACs}

The six peptides vary in the overall molecular hydrophobicity by having or having not the III segment and the number of the VPGVG unit. Moreover, all of the peptides are blocked at their C and $\mathrm{N}$ terminals, each one carrying two positive charges from the two $\mathrm{K}$ residues at the studied $\mathrm{pH}$ of $4.5 \pm 0.3$. The two charges either centralize on one terminal or distribute separately on the two terminals. Therefore, we can probe into the effects of molecular hydrophobicity and charge distribution on the peptide self-assembly behaviors.

First, the CAC of each peptide was determined using the pyrene fluorescence probe method $[48,49]$. The results are shown in Figure 1, where the pyrene polarity ratio $\left(\mathrm{I}_{1} / \mathrm{I}_{3}\right)$ was plotted as a function of peptide concentration. The CACs were determined from intersection of the extrapolations of the decreasing part of each curve and the nearly horizontal part at relatively higher concentrations [50]. 
The results are listed in Table 2. For K-K8 and KK8, the two 8-mer molecules with one VPGVG unit but no III segment, they all gave CACs of larger than $8.0 \mathrm{mM}$. For IK-K11 and IKK11, the two 11-mer molecules with one VPGVG unit linked to the III segment, they gave moderate CACs of around $2.65 \mathrm{mM}$ and $2.20 \mathrm{mM}$, respectively. While for IK-K16 and IKK16, the two 16-mer molecules with two VPGVG units, they gave much smaller CACs of about $0.94 \mathrm{mM}$ and $0.74 \mathrm{mM}$, respectively. The results clearly show that the CACs depend greatly on the molecular hydrophobicity, while the charge distribution has limited effect on the CACs of the peptides with the same length.

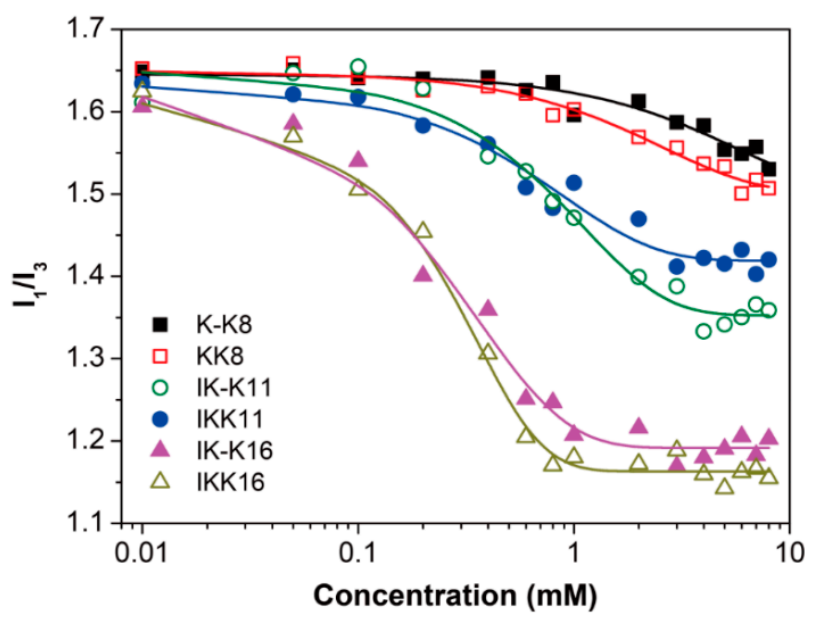

Figure 1. Variation of the pyrene polarity ratio $\mathrm{I}_{1} / \mathrm{I}_{3}$ with the peptide concentration.

Table 2. List of the CACs, the self-assembled structures and the corresponding size parameters of all peptides.

\begin{tabular}{|c|c|c|c|c|c|}
\hline \multirow{2}{*}{ Peptide } & \multirow{2}{*}{ Temperature } & \multirow{2}{*}{ CAC (mM) } & \multirow{2}{*}{ Self-Assembled Structures } & \multicolumn{2}{|c|}{ Size Parameters (nm) } \\
\hline & & & & Length & Diameter \\
\hline \multirow{2}{*}{$\mathrm{K}-\mathrm{K} 8$} & $20{ }^{\circ} \mathrm{C}$ & $>8.0$ & amorphous aggregates & - & - \\
\hline & $80^{\circ} \mathrm{C}$ & - & amorphous aggregates & - & - \\
\hline \multirow{2}{*}{ KK8 } & $20{ }^{\circ} \mathrm{C}$ & $>8.0$ & amorphous aggregates & - & - \\
\hline & $80^{\circ} \mathrm{C}$ & - & amorphous aggregates & - & - \\
\hline \multirow{2}{*}{ IK-K11 } & $20^{\circ} \mathrm{C}$ & $2.65 \pm 0.26$ & short fibrils & $<600$ & $11.0 \pm 2.5$ \\
\hline & $80^{\circ} \mathrm{C}$ & - & long smooth fibrils & $>1000$ & $15.0 \pm 8.0$ \\
\hline \multirow{2}{*}{ IKK11 } & $20{ }^{\circ} \mathrm{C}$ & $2.20 \pm 0.17$ & short fibrils & $<1200$ & $20.0 \pm 3.5$ \\
\hline & $80{ }^{\circ} \mathrm{C}$ & - & long smooth fibrils & $>1000$ & $12.0 \pm 2.0$ \\
\hline \multirow{2}{*}{ IK-K16 } & $20{ }^{\circ} \mathrm{C}$ & $0.94 \pm 0.11$ & long smooth fibrils & $>1000$ & $13.5 \pm 2.5$ \\
\hline & $80{ }^{\circ} \mathrm{C}$ & - & long smooth fibrils \& fibril bundles & $>1000$ & $14.0 \pm 2.0$ \\
\hline \multirow{2}{*}{ IKK16 } & $20{ }^{\circ} \mathrm{C}$ & $0.74 \pm 0.08$ & long rough fibrils & $>1000$ & $20.0 \pm 5.5$ \\
\hline & $80{ }^{\circ} \mathrm{C}$ & - & long smooth fibrils & $>2000$ & $11.0 \pm 1.0$ \\
\hline
\end{tabular}

\subsection{Morphologies of the Self-Assembled Structures}

The self-assembled structures of each peptide at $4.0 \mathrm{mM}$ and varied temperature were further investigated by TEM and AFM. Since the studied concentration was below the CACs of the 8-mer peptides, it is reasonable that K-K8 and KK8 both gave amorphous aggregates (Figure S1, Supporting Information). However, for the 11-mer and 16-mer peptides, they all self-assembled into distinct nanostructures whose morphologies showed dependence on temperature, as shown in Figure 2. IK-K11 formed short smooth fibrils with limited length of $<600 \mathrm{~nm}$ and a relatively uniform diameter of $11 \pm 2.5 \mathrm{~nm}$ at $20^{\circ} \mathrm{C}$. However, it gave long fibrils with length of several micrometers and diameter of a quite large range of $15 \pm 8 \mathrm{~nm}$ at $80^{\circ} \mathrm{C}$. The inset magnified TEM image in Figure 2e gave several fibrils with distinct substructures. Clearly the fibrils are comprised of thinner primary fibers with diameter of $\sim 4.0 \mathrm{~nm}$. The number of such primary fibers varied for each fibril, resulting in broad 
distribution of the fibril diameters. IKK11 also produced fibrils with limited length of $<1200 \mathrm{~nm}$ at $20^{\circ} \mathrm{C}$, which had smooth surface. Their diameters were quite large to be $20 \pm 3.5 \mathrm{~nm}$. The self-assembled nanostructures also turned into long fibrils of micrometers long at $80^{\circ} \mathrm{C}$, whilst the diameters became significantly smaller to be $12.0 \pm 2.0 \mathrm{~nm}$. The large difference in diameters indicates that the fibrils formed at $80{ }^{\circ} \mathrm{C}$ were not from elongation of the fibrils formed at $20{ }^{\circ} \mathrm{C}$. They might come from different self-assembling routes. The two 16-mer peptides exhibited quite different self-assembly behaviors. IK-K16 formed long smooth fibrils of micrometers in length and $13.5 \pm 2.5 \mathrm{~nm}$ in diameters at $20^{\circ} \mathrm{C}$. However, it produced two kinds of aggregates $80^{\circ} \mathrm{C}$, that is, the separate long fibrils and the aggregated fibril bundles. These fibrils had diameters of $14.0 \pm 2.0 \mathrm{~nm}$, approximately the same as the fibrils formed at $20^{\circ} \mathrm{C}$, indicating they were from the same assembly route. IKK16 also produced fibrils of micrometers long at $20^{\circ} \mathrm{C}$. However, the fibrils showed rough surfaces and their diameters were quite large to be $20.0 \pm 5.5 \mathrm{~nm}$. Interestingly, the fibrils produced by IKK 16 at $80{ }^{\circ} \mathrm{C}$ gave smooth surfaces and significantly smaller diameters of $11.0 \pm 1.0 \mathrm{~nm}$. Similar to the case of IKK11, here the differences in surface roughness and diameters also indicate the fibrils formed at $20{ }^{\circ} \mathrm{C}$ and $80{ }^{\circ} \mathrm{C}$ might come from different self-assembling routes. The self-assembled nanostructures of each peptide were also imaged by AFM. The results (Figure S2, Supporting Information) were well consistent with the TEM results.
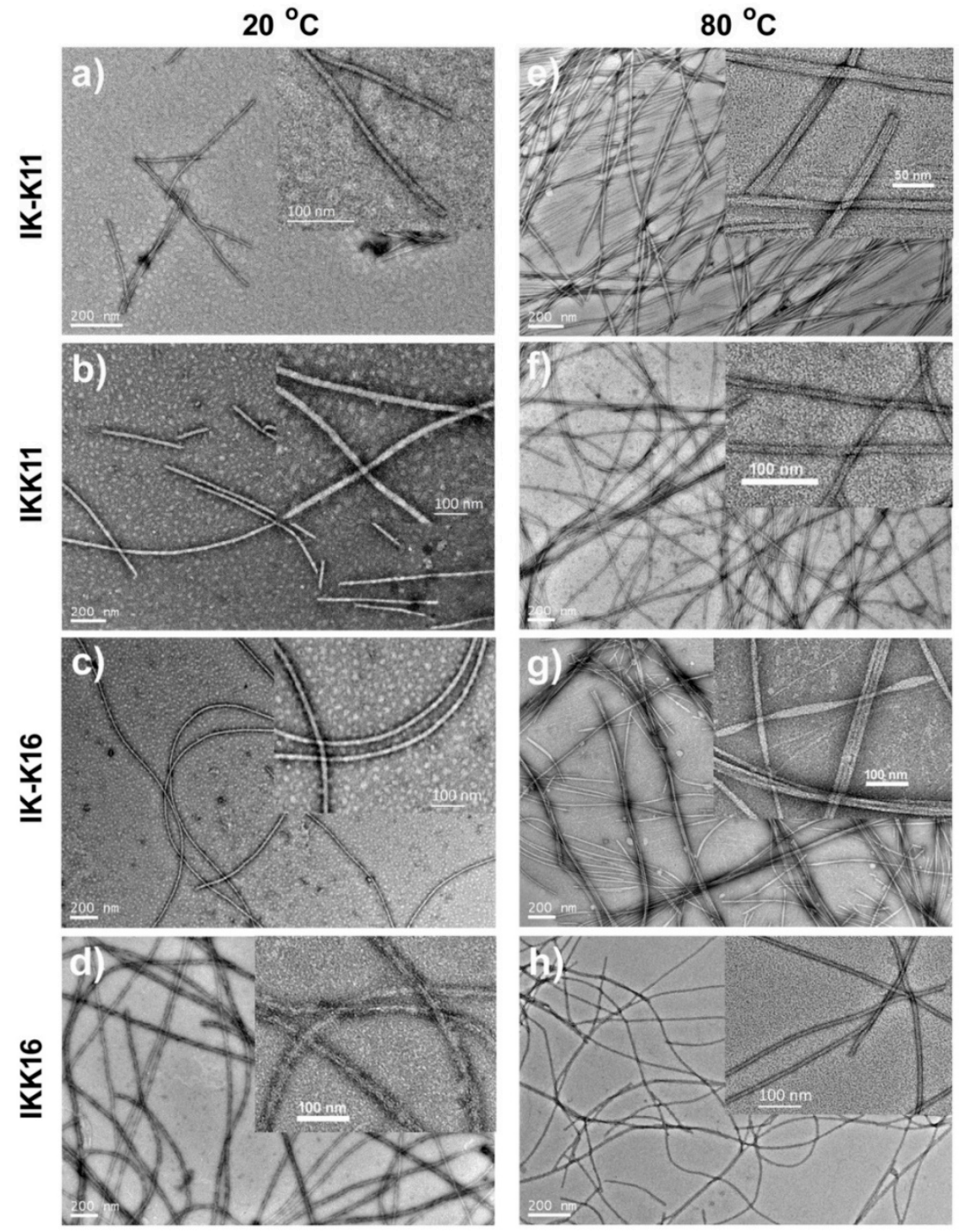

Figure 2. TEM morphologies show the self-assembled structures of different peptides at concentration of $4.0 \mathrm{mM}$ and temperature of either $20^{\circ} \mathrm{C}$ or $80^{\circ} \mathrm{C}$. 


\subsection{Secondary Structures at Varied Temperatures}

To further probe into the effect of temperature on peptide self-assembly, CD spectra of the peptide solutions were first obtained to infer the secondary structural change. Figure 3 presents the CD spectra of the peptide solutions of $4.0 \mathrm{mM}$ at different temperatures. The 11-mer and 16-mer peptides all gave negative bands with varied peak positions at $20^{\circ} \mathrm{C}$, that is, $218 \mathrm{~nm}$ for IK-K11, a broad band between 212 and $220 \mathrm{~nm}$ for IKK11, $222 \mathrm{~nm}$ for IK-K16, and $221 \mathrm{~nm}$ for IKK16, respectively. These negative bands near $220 \mathrm{~nm}$ can be ascribed to the $\mathrm{n}-\pi^{*}$ transition, indicating the $\beta$-sheet secondary structures [51], while shift in the peak position should be associated with distortion of $\beta$-sheets [52]. In fact, such CD spectra are typical for short elastin-like peptides [18,21,30]. FTIR measurements were further performed to confirm the secondary structures. The spectra (Figure S3) all showed characteristic peptide bands, that is, amide I, amide II and amide III bands. Specifically, the amide I region (Figure 4) for each peptide all gave a prominent band at $\sim 1630 \mathrm{~cm}^{-1}$ and two shoulders at $\sim 1665$ and $1673 \mathrm{~cm}^{-1}$. The peak at $1630 \mathrm{~cm}^{-1}$ can be ascribed to $\beta$-sheet secondary structure $[53,54]$, being in consistence with the CD results. The peak at $1673 \mathrm{~cm}^{-1}$ is suggested to indicate an antiparallel $\beta$-strand arrangement $[49,55]$.
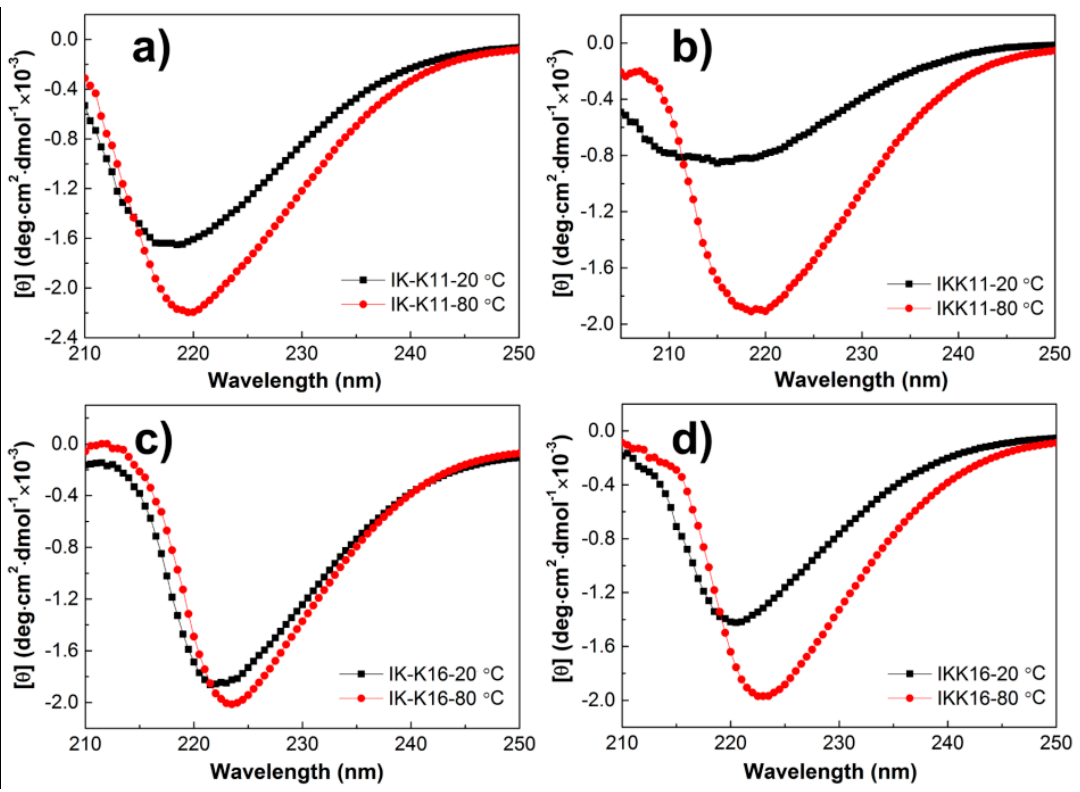

Figure 3. The CD spectra of different peptide solutions at concentration of $4.0 \mathrm{mM}$ and temperature of either $20^{\circ} \mathrm{C}$ or $80{ }^{\circ} \mathrm{C}$.

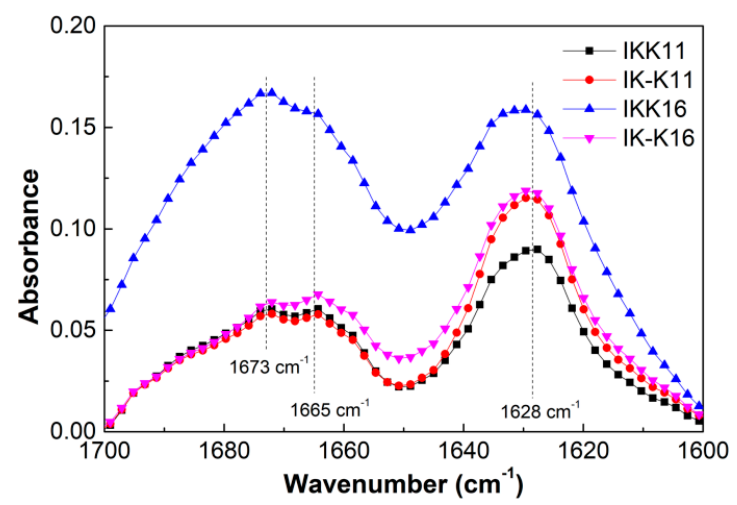

Figure 4. The amide I region of the FTIR spectra of different peptide solutions at concentration of $4.0 \mathrm{mM}$ and temperature of $20^{\circ} \mathrm{C}$. 
Comparing to the $\mathrm{CD}$ spectra at $20^{\circ} \mathrm{C}$, the spectra for each peptide at $80^{\circ} \mathrm{C}$ all gave an obvious increase in intensity as well as a slight red shift to larger wavelength. The intensity increase indicated that more $\beta$-sheets were formed in the solutions at higher temperature. It can be rationalized that the temperature increase promoted the self-assembly process by providing more energy. The shifts in peak wavelength indicated that the temperature increase also induced change in molecular conformations and arrangements, resulting in distortion of the $\beta$-sheets [52]. Moreover, the peptides with two positive charges on one terminal, that is, IKK11 and IKK16, gave larger increase in peak intensity than their counterparts of IK-K11 and IK-K16 with two positive charges separated on the two terminals. Taking also the morphological transitions of the self-assembled nanostructures into consideration, we deduce that the temperature increase not only promoted the self-assembly process but also induced change of the self-assembly routes of IKK11 and IKK16.

Previous studies demonstrated that the shorter elastin-like peptides were less-disordered than the longer peptides at low temperatures [21,30]. However, in current systems, IKK16 gave more negative peak than IKK11 and IK-K16 gave more negative peak than IK-K11 at $20{ }^{\circ} \mathrm{C}$, indicating that the longer peptides produced nanostructures with more ordered molecular arrangements. The phenomenon was proposed to be resulted from introduction of the highly hydrophobic III segment into the peptides, which greatly tuned the self-assembly behaviors.

For further probing into the effect of charge distribution on peptide self-assembly, we recorded the CD spectra of IK-K16 and IKK16 at varied temperatures during a gradual temperature increasing course. The results are shown in Figure 5. The gradual shift of the negative $\beta$-sheet peak towards larger wavelength with temperature increase can be clearly seen in Figure 5a. Since the peak intensity reflects the $\beta$-sheet content, dependence of the self-assembly extent on temperature was shown in Figure $5 \mathrm{~b}$ by plotting the peak intensity as a function of temperature. Comparing to IK-K16, IKK16 gave a more sharp decrease in $\theta$ value (increase in $\beta$-sheet content) with temperature increase. It indicated that the self-assembly of IKK16 (with two charges centralized on one terminal) showed higher dependence on temperature than IK-K16 (with two charges distributed separately on the two terminals).
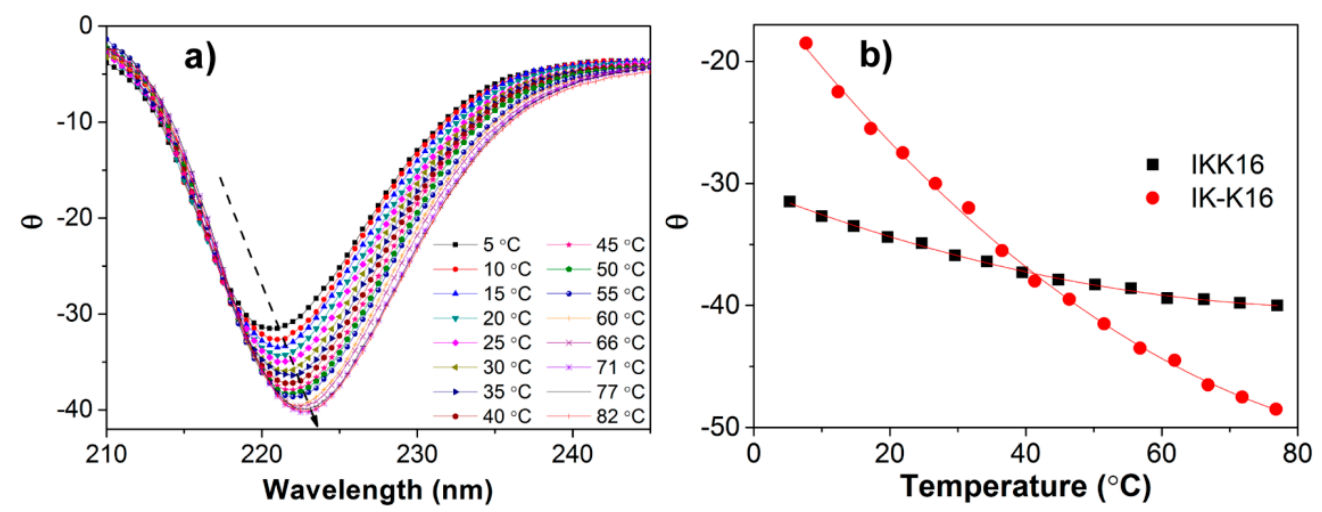

Figure 5. (a) The CD spectra of IKK16 solution $(4.0 \mathrm{mM})$ at different temperatures. (b) Variation of the intensity of the negative peak at $220-225 \mathrm{~nm}$ as a function of temperature.

\subsection{Effects of Molecular Hydrophobicity, Charge Distribution and Temperature on Peptide Self-assembly}

Several interesting experimental results can be concluded, which may find interpretation from the aspects of molecular hydrophobicity, charge distribution and temperature. First, the CACs decrease in the order of the 8-mer peptides, the 11-mer peptides and the 16-mer peptides, that is, the self-assembling capability increases with increasing chain length. This can be interpreted from the aspect of molecular hydrophobicity. As known, hydrophobic interaction is one of the main driving forces for peptide self-assembly. Here, the longer peptides have higher molecular hydrophobicity and reasonably give higher level of intermolecular hydrophobic interaction during self-assembly. This facilitates molecular aggregation at lower concentrations, that is, to give smaller CACs. 
Then, there are two interesting facts about the dimensions of the self-assembled structures at $20{ }^{\circ} \mathrm{C}$. One is that the two 11-mer peptides produced short fibrils with limited length while the two 16-mers produced long fibrils that seemed to have infinite length. The other is that IK-K11 and IK-K16, the peptides with the positive charges separated on the two terminals, gave smaller fibril diameters than their counterparts of IKK11 and IKK16, whose charges are centralized on one terminal. For all of these four peptides, the self-assembly driving forces should include hydrophobic interaction, hydrogen bonding and electrostatic interaction. These forces regulated the growth of the nanostructures along each dimension, and the interplay and balance determined the final self-assembled nanostructures $[43,49]$. First, the axial growth is driven by hydrogen bonding between $\beta$-strands in a directional way. Here it is apparent that the axial hydrogen bonding formation had excellent continuity in the cases of the 16-mer peptides while it was easily disrupted in the cases of the 11-mers. Since the four peptides all have two positive charges, electrostatic interaction should be approximately the same for them. However, as discussed in the above text, the 11-mers and the 16-mers had different levels of hydrophobic interaction due to their varied molecular hydrophobicity. The 11-mers had relatively weaker hydrophobic interaction, which might not be strong enough to afford the conformational distortion when hydrogen bonding was consecutively formed along the long axis, resulting in restricted fibril length. While for the 16-mer peptides, hydrophobic interaction was greatly enhanced, which could stabilize the aggregates and facilitate the axial hydrogen bonding for producing long fibrils. Then, for the fibril diameter, it should be mainly determined by the number of $\beta$-sheets that stacked along the zippering axis. The fibrils of these four peptides all had positive charges distributed on their surface, as evidenced by the positive zeta potentials of the peptide solutions (data not shown here). For IK-K11 and IK-K16, one positively charged Lys residue is connected to the III segment that formed the hydrophobic inner core during self-assembly. To expose this charge outward the peptide molecule should take a highly folded conformation. Such a conformation might be unfavorable for stable and continuous stacking of $\beta$-sheets along the zippering axis and therefore resulted in relatively smaller diameters.

For the effect of temperature, we can discuss from the following aspects. First, the temperature increase provided more energy to promote peptide self-assembly. This can be confirmed by the facts of both the growth of the fibril length and the increase in $\beta$-sheet content. Second, the temperature increase would change the molecular conformation by inducing the temperature-responsive VPGVG unit to fold. Such a conformational change might have case-dependent outcomes. One is that it enabled higher level of lateral association of the fibrils, as in the case of IK-K16. It might also change the self-assembling routes by passing through other energy barriers, as very likely in the cases of IKK11 and IKK16.

\section{Conclusions}

A series of short self-assembling peptides, that is, the 8-mer peptides of K-K8 and KK8, the 11-mer peptides of K-K11 and KK11, and the 16-mer peptides of K-K16 and KK16, have been designed and synthesized by introducing one or two elastomeric VPGVG units into the amphiphilic peptide molecules. The effects of molecular hydrophobicity, charge distribution and temperature on the peptide self-assembly behaviors were investigated. The results showed that the two 8-mer molecules with only one VPGVG unit but non III segment had quite low self-assembling ability and cannot form ordered structures at concentrations smaller than $8.0 \mathrm{mM}$. At lower temperature of $20^{\circ} \mathrm{C}$, the two 11-mer peptides self-assembled into short fibrils, whilst the two 16-mer peptides formed long fibrils. At higher temperature of $80{ }^{\circ} \mathrm{C}$, both the 11-mer and 16-mer peptides produced long fibrils and / or fibril bundles. For the two molecules with centralized charge distribution, that is, IKK11 and IKK16, the temperature increase can promote their self-assembly process as well as tune the self-assembly routes. Moreover, comparing to IK-K16 the self-assembly of IKK16 showed much higher dependence on temperature. The study demonstrates the exciting possibility of developing temperature-sensitive 
short self-assembling peptides by introducing the basic elastin $\beta$-turn units into the molecules, which is believed to be of great help for the construction of peptidic materials with functionality.

Supporting Information: The following are available online. TEM and AFM morphologies of the peptide selfassembled nanostructures.

Author Contributions: Conceptualization, M.C.; Methodology, M.C. and Y.S.; Software, Y.S., Y.W. and X.W.; Validation, Y.S., Y.W., X.W. and D.L.; Formal Analysis, M.W., Y.S. and Y.W.; Investigation, Y.S. and Y.W.; Resources, M.C.; Data Curation, M.C., Y.S. and X.W.; Writing-Original Draft Preparation, M.C.; Writing-Review \& Editing, M.C., X.W. and D.L.; Visualization, X.W.; Supervision, M.C.; Project Administration, M.C.; Funding Acquisition, M.C. and D.L.

Funding: This work was supported by the National Natural Science Foundation of China (21872173, 21473255), the Fundamental Research Funds for the Central Universities (17CX02050) and the open research funds from the Key Laboratory of Applied Surface and Colloid Chemistry (Shaanxi Normal University) and Qingdao University of Science and Technology (QUSTHX201803).

Conflicts of Interest: The authors declare that they have no conflict of interest.

\section{References}

1. Urry, D.W. Physical chemistry of biological free energy transduction as demonstrated by elastic protein-based polymers. J. Phys. Chem. B 1997, 101, 11007-11028. [CrossRef]

2. Mithieux, S.M.; Weiss, A.S. Elastin. In Advances in Protein Chemistry; Elsevier Inc.: Amsterdam, The Netherlands, 2005; pp. 437-461.

3. Debelle, L.; Tamburro, A.M. Elastin: Molecular description and function. Int. J. Biochem. Cell Biol. 1999, 31, 261-272. [CrossRef]

4. Yeo, G.C.; Aghaei-Ghareh-Bolagh, B.; Brackenreg, E.P.; Hiob, M.A.; Lee, P.; Weiss, A.S. Fabricated elastin. Adv. Healthc. Mater. 2015, 4, 2530-2556. [CrossRef] [PubMed]

5. Urry, D.W. Molecular machines: How motion and other functions of living organisms can result from reversible chemical changes. Angew. Chem. Int. Ed. Engl. 1993, 32, 819-841. [CrossRef]

6. Raju, K.; Anwar, R.A. Primary structures of bovine elastin a, b, and c deduced from the sequences of cDNA clones. J. Biol. Chem. 1987, 262, 5755-5762. [PubMed]

7. Indik, Z.; Yeh, H.; Ornstein-Goldstein, N.; Sheppard, P.; Anderson, N.; Rosenbloom, J.C.; Peltonen, L.; Rosenbloom, J. Alternative splicing of human elastin mRNA indicated by sequence analysis of cloned genomic and complementary DNA. Proc. Natl. Acad. Sci. USA 1987, 84, 5680-5684. [CrossRef] [PubMed]

8. Yeh, H.; Ornstein-Goldstein, N.; Indik, Z.; Sheppard, P.; Anderson, N.; Rosenbloom, J.C.; Cicila, G.; Yoon, K.; Rosenbloom, J. Sequence variation of bovine elastin mRNA due to alternative splicing. Coll. Relat. Res. 1987, 7, 235-247. [CrossRef]

9. Sandberg, L.B.; Leslie, J.G.; Leach, C.T.; Alvarez, V.L.; Torres, A.R.; Smith, D.W. Elastin covalent structure as determined by solid phase amino acid sequencing. Pathol. Biol. 1985, 33, 266-274.

10. Quiroz, F.G.; Chilkoti, A. Sequence heuristics to encode phase behaviour in intrinsically disordered protein polymers. Nat. Mater. 2015, 14, 1164-1171. [CrossRef]

11. McDaniel, J.R.; Radford, D.C.; Chilkoti, A. A unified model for de novo design of elastin-like polypeptides with tunable inverse transition temperatures. Biomacromolecules 2013, 14, 2866-2872. [CrossRef]

12. Wang, H.; Paul, A.; Nguyen, D.; Enejder, A.; Heilshorn, S.C. Tunable control of hydrogel microstructure by kinetic competition between self-assembly and crosslinking of elastin-like proteins. ACS Appl. Mater. Interfaces 2018, 10, 21808-21815. [CrossRef] [PubMed]

13. Meyer, D.E.; Kong, G.A.; Dewhirst, M.W.; Zalutsky, M.R.; Chilkoti, A. Targeting a genetically engineered elastin-like polypeptide to solid tumors by local hyperthermia. Cancer Res. 2001, 61, 1548-1554. [PubMed]

14. Reiersen, H.; Rees, A.R. Sodium sulphate reactivates a protein a minidomain with a short elastin $\beta$-Turn. Biochem. Biophys. Res. Commun. 2000, 276, 899-904. [CrossRef] [PubMed]

15. Cook, W.J; Einspahr, H.; Trapane, T.L.; Urry, D.W.; Bugg, C.E. Crystal structure and conformation of the cyclic trimer of a repeat pentapeptide of elastin, cyclo-(L-valyl-L-prolylglycyl-L-valylglycyl)3. J. Am. Chem. Soc. 1980, 102, 5502-5505. [CrossRef] 
16. Khaled, M.A.; Venkatachalam, C.M.; Sugano, H.; Urry, D.W. Conformational characterization of cyclopentapeptide, lval-lpro-gly-lval-gly a repeating analogue of elastin. Int. J. Pept. Protein Res. 1981, 17, 23-33. [CrossRef] [PubMed]

17. Yao, X.L.; Hong, M. Structure distribution in an elastin-mimetic peptide (VPGVG)3 investigated by solid-State NMR. J. Am. Chem. Soc. 2004, 126, 4199-4210. [CrossRef]

18. Urry, D.W.; Mitchell, L.W.; Ohnishi, T. Studies on the conformation and interactions of elastin secondary structure of synthetic repeat hexapeptides. BBA-Protein Struct. 1975, 393, 296-306. [CrossRef]

19. Urry, D.W.; Long, M.M.; Sugano, H. Cyclic analog of elastin polyhexapeptide exhibits an inverse temperature transition leading to crystallization. J. Biol. Chem. 1978, 253, 6301-6302.

20. Schreiner, E.; Nicolini, C.; Ludolph, B.; Ravindra, R.; Otte, N.; Kohlmeyer, A.; Rousseau, R.; Winter, R.; Marx, D. Folding and unfolding of an elastinlike oligopeptide: "inverse temperature transition," reentrance, and hydrogen-bond dynamics. Phys. Rev. Lett. 2004, 92, 148101. [CrossRef]

21. Reiersen, H.; Clarke, A.R.; Rees, A.R. Short elastin-like peptides exhibit the same temperature-induced structural transitions as elastin polymers: Implications for protein engineering. J. Mol. Biol. 1998, 283, 255-264. [CrossRef]

22. Pechar, M.; Brus, J.; Kostka, L.; Koňák, Č.; Urbanová, M.; Šlouf, M. Thermoresponsive self-assembly of short elastin-like polypentapeptides and their poly(ethylene glycol) derivatives. Macromol. Biosci. 2007, 7, 56-69. [CrossRef]

23. Flamia, R.; Salvi, A.M.; D'Alessio, L.; Castle, J.E.; Tamburro, A.M. Transformation of amyloid-like fibers, formed from an elastin-based biopolymer, into a hydrogel: an X-ray photoelectron spectroscopy and atomic force microscopy study. Biomacromolecules 2006, 8, 128-138. [CrossRef] [PubMed]

24. Baer, M.; Schreiner, E.; Kohlmeyer, A.; Rousseau, R.; Marx, D. Inverse temperature transition of a biomimetic elastin model: reactive flux analysis of folding/unfolding and its coupling to solvent dielectric relaxation. J. Phys. Chem. B 2006, 110, 3576-3587. [CrossRef] [PubMed]

25. Glaves, R.; Baer, M.; Schreiner, E.; Stoll, R.; Marx, D. Conformational dynamics of minimal elastin-like polypeptides: The role of proline revealed by molecular dynamics and nuclear magnetic resonance. ChemPhysChem 2008, 9, 2759-2765. [CrossRef] [PubMed]

26. Patel, D.; Menon, R.; Taite, L.J. Self-assembly of elastin-based peptides into the ECM: The importance of integrins and the elastin binding protein in elastic fiber assembly. Biomacromolecules 2011, 12, 432-440. [CrossRef] [PubMed]

27. Koga, T.; Nakamoto, K.; Odawara, K.; Matsuoka, T.; Higashi, N. Fabrication of thermo-responsive molecular layers from self-assembling elastin-like oligopeptides containing cell-binding domain for tissue engineering. Polymers 2015, 7, 134. [CrossRef]

28. Taniguchi, S.; Watanabe, N.; Nose, T.; Maeda, I. Development of short and highly potent self-assembling elastin-derived pentapeptide repeats containing aromatic amino acid residues. J. Peptide Sci. 2016, 22, 36-42. [CrossRef] [PubMed]

29. Bochicchio, B.; Pepe, A.; Crudele, M.; Belloy, N.; Baud, S.; Dauchez, M. Tuning self-assembly in elastinderived peptides. Soft Matter 2015, 11, 3385-3395. [CrossRef] [PubMed]

30. Nuhn, H.; Klok, H.-A. Secondary structure formation and LCST behavior of short elastin-like peptides. Biomacromolecules 2008, 9, 2755-2763. [CrossRef]

31. Iori, M.; Suguru, T.; Junko, E.; Noriko, W.; Takao, H.; Takeru, N. Comparison between coacervation property and secondary structure of synthetic peptides, Ile-containing elastin-derived pentapeptide repeats. Protein Peptide Lett. 2013, 20, 905-910.

32. Suyama, K.; Tatsubo, D.; Iwasaki, W.; Miyazaki, M.; Kiyota, Y.; Takahashi, I.; Maeda, I.; Nose, T. Enhancement of self-aggregation properties of linear elastin-derived short peptides by simple cyclization: Strong self-aggregation properties of cyclo[FPGVG]n, consisting only of natural amino acids. Biomacromolecules 2018, 19, 3201-3211. [CrossRef] [PubMed]

33. Scelsi, A.; Bochicchio, B.; Smith, A.; Saiani, A.; Pepe, A. Nanospheres from the self-assembly of an elastin-inspired triblock peptide. RSC Adv. 2015, 5, 95007-95013. [CrossRef]

34. Wang, J.; Liu, K.; Xing, R.; Yan, X. Peptide self-assembly: Thermodynamics and kinetics. Chem. Soc. Rev. 2016, 45, 5589-5604. [CrossRef]

35. Jeong, W.-J.; Kwon, S.H.; Lim, Y.-B. Modular self-assembling peptide platform with a tunable thermoresponsiveness via a single amino acid substitution. Adv. Funct. Mater. 2018, 28, 1803114. [CrossRef] 
36. Zhao, X.; Pan, F.; Xu, H.; Yaseen, M.; Shan, H.; Hauser, C.A.E.; Zhang, S.; Lu, J.R. Molecular self-assembly and applications of designer peptide amphiphiles. Chem. Soc. Rev. 2010, 39, 3480-3498. [CrossRef]

37. Zhang, S. Fabrication of novel biomaterials through molecular self-assembly. Nat. Biotech. 2003, 21, 1171-1178. [CrossRef]

38. Reches, M.; Gazit, E. Casting metal nanowires within discrete self-assembled peptide nanotubes. Science 2003, 300, 625-627. [CrossRef]

39. Kim, T.G.; Shin, H.; Lim, D.W. Biomimetic scaffolds for tissue engineering. Adv. Funct. Mater. 2012, 22, 2446-2468. [CrossRef]

40. Dou, X.-Q.; Feng, C.-L. Amino acids and peptide-based supramolecular hydrogels for three-dimensional cell culture. Adv. Mater. 2017, 29, 1604062. [CrossRef] [PubMed]

41. Rad-Malekshahi, M.; Lempsink, L.; Amidi, M.; Hennink, W.E.; Mastrobattista, E. Biomedical applications of self-assembling peptides. Bioconjugate Chem. 2016, 27, 3-18. [CrossRef] [PubMed]

42. Cao, M.; Wang, Y.; Zhao, W.; Qi, R.; Han, Y.; Wu, R.; Wang, Y.; Xu, H. Peptide-induced DNA condensation into virus-mimicking nanostructures. ACS Appl. Mater. Interfaces 2018, 10, 24349-24360. [CrossRef] [PubMed]

43. Cao, M.; Lu, S.; Zhao, W.; Deng, L.; Wang, M.; Wang, J.; Zhou, P.; Wang, D.; Xu, H.; Lu, J.R. Peptide self-assembled nanostructures with distinct morphologies and properties fabricated by molecular design. ACS Appl. Mater. Interfaces 2017, 9, 39174-39184. [CrossRef] [PubMed]

44. Yang, H.; Pritzker, M.; Fung, S.Y.; Sheng, Y.; Wang, W.; Chen, P. Anion effect on the nanostructure of a metal ion binding self-assembling peptide. Langmuir 2006, 22, 8553-8562. [CrossRef] [PubMed]

45. Mart, R.J.; Osborne, R.D.; Stevens, M.M.; Ulijn, R.V. Peptide-based stimuli-responsive biomaterials. Soft Matter 2006, 2, 822-835. [CrossRef]

46. Xu, H.; Wang, Y.; Ge, X.; Han, S.; Wang, S.; Zhou, P.; Shan, H.; Zhao, X.; Lu, J.R. Twisted nanotubes formed from ultrashort amphiphilic peptide I3K and their templating for the fabrication of silica nanotubes. Chem.Mater. 2010, 22, 5165-5173. [CrossRef]

47. Wang, S.; Ge, X.; Xue, J.; Fan, H.; Mu, L.; Li, Y.; Xu, H.; Lu, J.R. Mechanistic processes underlying biomimetic synthesis of silica nanotubes from self-assembled ultrashort peptide templates. Chem. Mater. 2011, 23, 2466-2474. [CrossRef]

48. Castelletto, V.; Hamley, I.W. Self assembly of a model amphiphilic phenylalanine peptide/polyethylene glycol block copolymer in aqueous solution. Biophys. Chem. 2009, 141, 169-174. [CrossRef]

49. Cao, M.; Cao, C.; Zhang, L.; Xia, D.; Xu, H. Tuning of peptide assembly through force balance adjustment. J. Colloid Interface Sci. 2013, 407, 287-295. [CrossRef]

50. Aguiar, J.; Carpena, P.; Molina-Bolívar, J.A.; Carnero Ruiz, C. On the determination of the critical micelle concentration by the pyrene 1:3 ratio method. J. Colloid Interface Sci. 2003, 258, 116-122. [CrossRef]

51. Arad, O.; Goodman, M. Depsipeptide analogues of elastin repeating sequences: Conformational analysis. Biopolymers 1990, 29, 1651-1668. [CrossRef]

52. Paramonov, S.E.; Jun, H.W.; Hartgerink, J.D. Self-assembly of peptide-amphiphile nanofibers: The roles of hydrogen bonding and amphiphilic packing. J. Am. Chem. Soc. 2006, 128, 7291-7298. [CrossRef] [PubMed]

53. Pelton, J.T.; McLean, L.R. Spectroscopic methods for analysis of protein secondary structure. Anal. Biochem. 2000, 277, 167-176. [CrossRef] [PubMed]

54. Cao, M.; Cao, C.; Zhou, P.; Wang, N.; Wang, D.; Wang, J.; Xia, D.; Xu, H. Self-assembly of amphiphilic peptides: Effects of the single-chain-to-gemini structural transition and the side chain groups. Colloids Surf. A 2015, 469, 263-270. [CrossRef]

55. Mazor, Y.; Gilead, S.; Benhar, I.; Gazit, E. Identification and characterization of a novel molecular-recognition and self-assembly domain within the Islet amyloid polypeptide. J. Mol. Biol. 2002, 322, 1013-1024. [CrossRef]

Sample Availability: Samples of the compounds are not available from the authors. 